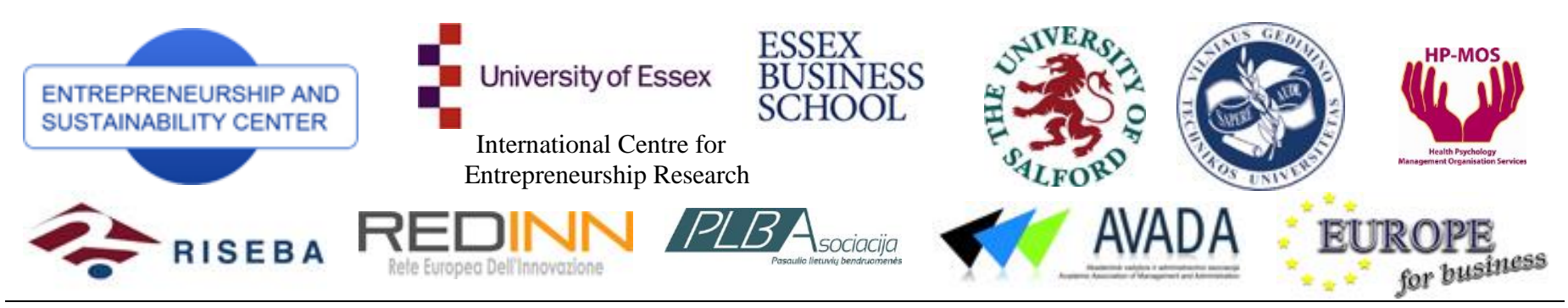

ENTREPRENEURSHIP AND SUSTAINABILITY ISSUES

ISSN 2345-0282 (online) http://jssidoi.org/jesi/aims-and-scope-of-research/

\title{
SUSTAINABLE ENTREPRENEURSHIP THROUGH MOTIVATION: CASE OF LATVIAN COMPANIES
}

\author{
Žanna Caurkubule ${ }^{1}$, Aleksandrs Rubanovskis ${ }^{2}$ \\ ${ }^{1,2}$ Baltic Psychology and Management University College, Lomonosova iela 4, Rīga, Latvia \\ E-mails:1rector@psy.lv; ${ }^{2}$ antraru@inbox.lv
}

Received 20 March 2014; accepted 15 June 2014

\begin{abstract}
The article aims to provide analysis of situation, common tendencies and problems of material and non-material personnel motivation in Latvia in the conditions of economic transformation. It is considered that appropriate stimulation mechanisms at the company level would facilitate sustainable entrepreneurship process. Authors claim, that meeting material and non-material needs of employees would lead to enhancement of viability of business companies. Motivation systems in various countries are being compared and suggestions formulated.
\end{abstract}

Keywords: motivation theories, motivation system, labor market, human resources, Latvia

Reference to this paper should be made as follows: Caurkubule, Z.; Rubanovskis, A. 2014. Sustainable entrepreneurship through motivation: case of Latvian companies, Entrepreneurship and Sustainability Issues 2(1): 43-48.

DOI: http://dx.doi.org/10.9770/jesi.2014.2.1(6)

JEL Classifications: F66

\section{Introduction}

In the conditions of permanent competition business companies strive to use efficiently resources employed. Sustainable entrepreneurship (Wahl, Prause 2013; Dzemyda, Raudeliūnienè 2014; Tvaronavičienè 2014; Figurska 2014; Wahl 2014; Šabasevičienè, Grybaitė 2014, Tvaronavičienè et al. 2014; Raudeliūnienė et al. 2014, Vasiliūnaite 2014) requires paying attention at multiple factors affecting companies' performance and choose respective management tools allowing efficient financial management (Garškaitė-Milvydienè 2014; Baikovs, Zariņš 2013; De Alencar, Almeida 2013), all scope of innovation management (Litvaj, Poniščiaková 2014; Tvaronavičienè 2014), and, of course, well-tuned system of labour force management (Išoraite 2013; Raišienė, Jonušauskas 2013; Laužikas, Mokšeckienè 2013; Išoraitè et al. 2014; Caurkubule, Rubanovskis 2014) is required. In this paper we will tackle employees' motivation mechanism, which is major constitute of labour management system. Labour (employees') motivation is being considered as one of the main factors affecting labour productivity. Motivated personnel is one of preconditions of successful sustainable entrepreneurship, and ultimately, one of factors contributing to sustainable development of industries (Korsakienè, Tvaronavičienè 2014; Tvaronavičienè 2014) and countries (Vasiliūnaitè 2014).

Research objective: to develop proposals to improve efficiency of the use of human resources in Latvia through improvement of motivational mechanisms of personnel management. Research tasks: to analyze trends in the development of personnel motivation systems in the developed world; to investigate problems with the motivation of staff in the enterprises of Latvia; to make a comparative analysis of methods of motivation used at 
Western, Russian and Latvian companies; to develop proposals for improving the system of personnel motivation as an important condition for an effective use of human capital in economic development of the region. Object of study - labour market of Latvia, subject of research - motivation of labour at Latvian enterprises. Research methodology: the method of comparative analysis is used in the research, as well as content analysis, and systems methodology and systemic approach are used in developing proposals.

\section{Results and discussion}

Motivation of personnel is the main mean for providing optimum use of labour resources and for mobilization of existent labour potential. Speaking in numerals, motivation is the process, which leads to detraction of difference between amount of repaid hours and amount of worked hours, and, accordingly advanced to decrease of company expenditures. Notion "motivation" is uncommon for economic science, but during the last years literature published in the field of personnel management revealed interest and contribution of economists. For many years worker, as such, was considered only as the element of production process and approaches to methods of his management were simplified to the level of material elements management, provided process of production. Thus many psycho physiological factors were not considered, eliminated macro environmental influence over workers attitude to the process of work, management decisions were not considered as factor which determine economic success of entrepreneurial company.

Labor productivity is directly affected by employees' motivation. Hence building of efficient motivation system becomes task number one for Latvian employers. According to American scientist Edwin Lock, formation of effective motivation system makes possible to rise productivity of labour by $30 \%$ (according our observations, $90 \%$ of all companies, which took part in this investigation experienced increase of productivity by $10 \%$ ). Employees at Gallup organization studied 7939 detachments in 36 companies in the world and came to conclusion that key ratios of business profit always ensued high level of workers motivation (Buckinham and Clifton 2001).

Conclusions of London Economic School researches, which took part together with University of Sheffield are based on the following results: personnel motivation gives $19 \%$ profit rising, research and output- $6 \%$, new technologies-1 \% (Gratton 2005). Research of Harvard University in 20th years last century was managed not by economist but by professor of Psychology from Australia Elton Mayo (2007), what signals of importance of physiology in motivation system. Western School traditionally is based on an experiment. And at this time experiment, which was called Hottorn, it for the first time paid attention not to factors of production activity, but to attitude to workers. It gave start to theory of people relations (Mayo Elton 2007) Thus E. Mayo for the first time put in the epicentre management science not economic but psychological tasks. Conversely, it served for rise of whole row of motivation theories: theory "consumer hierarchy of needs" by A. Maslow (1954); theory "x and y" by D. McGregor (2006.); theory ERG by K. Aldelfer (1972) two factors motivation theory by F.Herzberg (1959) theory expectation by V.Vroom (1964); theory fairness by J. Adams (1982) Porter and Lawler (968) and Atkinson (1964) models etc. Achievements of Western management science in this field are evident, however far not all companies are able to accept lessons of new school management. Especially it is topical for small and middle business, which pay too little attention to motivation of their own employees. Many managers still follow simplicity and pragmatism, do not consider necessity systemic approach to motivation tools. Therefore, research task in the area of personnel management is to form gradually understanding of labour motivation process, which is adequate to modern economic development, and to instil awareness about contemporary personnel management.

Motivation in various business systems works via assessment of personnel action that is why it connects psychological and economical aspects. One of the most effective models of assessment working places is methodology of Edvard Hay, which allowed to arrange posts by computing summary grade of post. In ordinary form post is assessed in following way (Ivakina 2009):

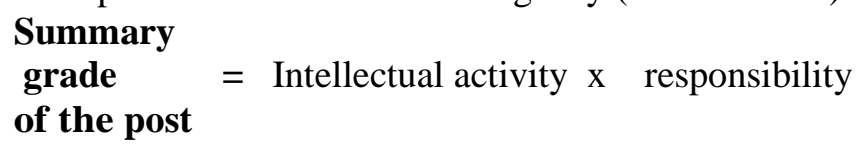


It has to be noticed, that it is doubtful whether the suggested above methodology can be used in small and middle business companies. "Floating" system of payment has been used in business-systems for years. E.g. in the USA 72,6\% of earnings is being received as regular fixed wage; additional part depends on achieved results. The latter part is divided between medical insurance, holiday pay and other payments from "social package" (Motivation and remuneration system). Many psychologists indicate that indirect material stimulation (social package) gives, so-called "effective effect", i.e. promotes collective unite, decreases turnover of personnel. Besides that, such form of motivation usually costs less for company, than direct material distinction. (Spitzer 1995) According some data, typical floating system may raise organizational productivity by $549 \%$, while workers income may increase only by 3-29\%. (Zhulina, Ivanova 2007). Individual motivation cannot be mechanically used for collective motivation reasons.

Researches of labour motivation by Tapani Alkula (1990) in Finland show, that for the workers of organization, where they work, organization is the place, where they spend significant part of their time and therefore for them environment and distinction are very important. Looking at the problem about attitude to work, T. Alkula ca1culates index of "workers effort" by formula: $\mathrm{s}=\mathbf{w} / \mathbf{c}$, where $\mathrm{w}$ - amount of the working places; $\mathrm{c}$ - common amount of the days in a year. For inhabitants of desert Kalahari this index is 0,11 - 0,31, and for at standard European family $(2+2)-0,36$ respectively. Looking at the problem of responsibility between work and social life, he uses data about Sweden and Finland. In both states the meaning of work for individual's life has tendency to diminish. In Sweden importance of social life is growing and in Finland because of strong Protestant ethics role of family is increasing (Zhulina, Ivanova 2007). Companies with right approach to motivation strive to coordinate private motives of workers with goals of the company by linking stimulation system to strategic goals of company by introducing KPI (key performance indicators).

Latvia's situation could be reflected by results of sociological inquiry. 550 respondents were chosen. The results indicated that the most powerful stimuli are: wages - 75\%, possibility of self-realization - $8 \%$, social status - 7\%, communication $-8 \%$. In the research, performed by the company TNS Latvia in 2011-2013, 850 businessmen from Latvia, Lithuania and Estonia were questioned. As it turned out, in Latvia only one third of businessmen considers, that the most important motive for good work must be good wage (in Estonia such managers still less - 25\%). The most important motive, as considered Baltic managers, is to involve their workers in the decision making process. Further follows necessity to share information with personnel about the plans and goa1s of the company; after that to make positive appreciation and testimonial; and only on the fourth place, among the main motives, is the high wage (Table 1).

Table 1. Forms of personnel motivation in the companies of Latvia, Lithuania and Estonia

\begin{tabular}{|l|l|l|l|l|}
\hline No & Factors of motivation & Latvia & Lithuania & Estonia \\
\hline 1. & $\begin{array}{l}\text { Involving workers in the process of } \\
\text { making decisions }\end{array}$ & 70 & 77 & 78 \\
\hline 2. & $\begin{array}{l}\text { Necessity to share in the information } \\
\text { about plans and goals }\end{array}$ & 59 & 64 & 58 \\
\hline 3. & Positive appreciations and testimonials & 32 & 33 & 40 \\
\hline 4. & Good wages and other material stimulation & 30 & 34 & 25 \\
\hline 5. & $\begin{array}{l}\text { Pleasant working environment (premises, } \\
\text { equipment) }\end{array}$ & 19 & 26 & 31 \\
\hline 6. & Interest about personnel work and feelings & 28 & 21 & 29 \\
\hline 7. & $\begin{array}{l}\text { Detailed exposition about the importance } \\
\text { of their work }\end{array}$ & 29 & 16 & 22 \\
\hline 8. & Offering of the interesting tasks & 25 & 17 & 14 \\
\hline
\end{tabular}

Source: According to data of company TNS Latvia (Improvement of a labor market in the country has positive impact on indicators of employees' loyalty). 
Researches, carried out by company Eiro Personāls, (Motivational system) show that Latvian managers still do not take into account importance of factors influencing satisfaction at work. E.g. in Great Britain three fourths of inhabitants are satisfied with their work and the great part of respondents (78\%) emphasizes that stimulus attract them to their work. As experience of Eiro Personals shows, in Latvia workers more often are not satisfied with the low wages, but there are more factors:

1.- image of the company, which ipacts satisfaction;

2.- managers (style of leadership);

3.- colleagues (atmosphere, or philological climate);

4.- common unsatisfactory while evaluating work conditions.

Table 2. Methods of motivation in the Western, Russian and Latvian companies

\begin{tabular}{|l|l|l|l|}
\hline Components of motivational & Frequency of using deductions & \multicolumn{2}{|l|}{$\begin{array}{l}\text { Western } \\
\text { companies }\end{array}$} \\
\hline package & $\begin{array}{l}\text { Russian } \\
\text { companies }\end{array}$ & Always & Companies \\
\hline Payment of mobile communication & $\begin{array}{l}\text { Almost } \\
\text { always }\end{array}$ & $\begin{array}{c}\text { Almost } \\
\text { Always }\end{array}$ \\
\hline Study expenses & Always & Always & Often \\
\hline Meals & Seldom & Often & Seldom \\
\hline Transport expenses, company's car & Often & Often & Often \\
\hline Medical insurance & Seldom & Often & Often \\
\hline Life insurance & Hardly ever & Often & Seldom \\
\hline Company's pension plan & Seldom & Often & Hardly ever \\
\hline Club cards (fitness) & Seldom & Often & Seldom \\
\hline Material relief & Often & Seldom & Seldom \\
\hline Deduction system & Often & Seldom & Often \\
\hline
\end{tabular}

Source: According data of company "Anchor" (Home page of company “Anchor”), firm SN personnel (Home page of agency CN Personnel) and Pedersen \& Partners (Home page of agency Pedersen\&Partners)

Hence, in order to achieve goals of the company, it is necessary to know how to motivate workers. Other motives then provided above, are: training, making a career, satisfaction with performed work etc.

Below we provide motivation research results of British experts (Table 2).

\section{Conclusions}

Motivation is not universal, so ad hoc motivation systems have to be build, as he most important aspects of motivation are economical, management and psychological aspects, which in its turn, explain attention to motivational problems such scientific subjects as economic, management and psychology. Such integral approach to the problems of personnel motivation at the end makes synergetic effect during the formation the system of personnel motivation of the company. In its turn, using non-coordinate approach sooner will drive to breaking down, but not to strengthening of personnel motivation to effective work.

The most important factors affecting motivation to work are: mood, climate, culture and informal relations in the company. Motivation is not easy to measure but it is crucial to understand its mechanism and peculiarities. Material and immaterial labor motivation must be flexible enough, but at the same time sustainable, in terms of fostering sustainable entrepreneurship. 


\section{References}

Adams, J. S., 1982. Inequity in Social Exchange, in Berkowitz, L. (Ed.). Advances in Experimental Social Psychology, 267-300. New York: Academic Press.

Alkula, T. 1990. Work orientations in Finland: A conceptual critique and empirical study of work-related expectations. Finnish Society of Sciences and Letters.

Alderfer, C. P. 1972. Existence, Relatedness, and Growth; Human Needs in Organizational Settings. New York: Free Press.

Atkinson, J. 1964. An introduction to Motivation. N.Y., Van Nostrand.

Baikovs, A.; Zariņš, I. 2013. Philosophical, legal and general issues of legal liability, Entrepreneurship and Sustainability Issues 1(1): 2336. DOI: http://dx.doi.org/10.9770/jesi.2013.1.1(3)

Buckinham, M.; Clifton, D. O. 2001. Now Discover Your Strengths. New York: Simon\&Schuster.

De Alencar, L.M.; Almeida, H.N. 2013. Economic viability and sustainability of solidarity economy enterprises: a case study on the technological incubator of popular cooperatives of the Catholic University of Salvador, Entrepreneurship and Sustainability Issues 1(2): 92-98. DOI: http://dx.doi.org/10.9770/jesi.2013.1.2(3)

Garškaitè-Milvydienè, K. 2014. Anti-crisis management of enterprises and possibilities of overcoming their critical condition, Entrepreneurship and Sustainability Issues 1(4): 187-203. DOI: http://dx.doi.org/10.9770/jesi.2014.1.4(1)

Litvaj, I.; Poniščiaková, O. 2014.Entrepreneurship and quality management, Entrepreneurship and Sustainability Issues 1(4): $204-209$. DOI: http://dx.doi.org/10.9770/jesi.2014.1.4(2)

Figurska, I. 2014.Sustainable entrepreneurship: localization, acquiring and use of knowledge sources in competitive organization, Entrepreneurship $\quad$ and Sustainability $\quad$ Issues 1(4): 210-222. DOI: http://dx.doi.org/10.9770/jesi.2014.1.4(3)

Wahl, M. 2014. Sustainable Entrepreneurship: The Wolf ButterBack Case, Entrepreneurship and Sustainability Issues 1(4): $223-229$. DOI: http://dx.doi.org/10.9770/jesi.2014.1.4(4)

Šabasevičienė, V.; Grybaite, V. 2014. Main foreign direct investment factors as precondition of sustainable entrepreneurship: evidence from Lithuania, Central and Eastern Europe, Entrepreneurship and Sustainability Issues 1(4): 230-238. DOI: http://dx.doi.org/10.9770/jesi.2014.1.4(5)

Išoraitè, M.; Steiblienė, L.; Mečèjienė, G. 2014. If obtained professional competences are suitable for sustainable entrepreneurship: case of Vilnius University of Applied Sciences, Entrepreneurship and Sustainability Issues 1(4): $239-246$. DOI: http://dx.doi.org/10.9770/jesi.2014.1.4(6)

Dzemyda, I.; Raudeliūnienè, J. 2014. Sustainable youth entrepreneurship in conditions of global economy toward energy security, Entrepreneurship and Sustainability Issues 1(4): 247-256. DOI: http://dx.doi.org/10.9770/jesi.2014.1.4(7)

Gratton, L. 2005. Demokraticheskoe ghtdprijatije. Raskreposchenije biznesa blagodarja svobode, gibkosti u priverzhennosti.: Stokgolmskaja shkola ekonomiki v Sankt-Peterburge [The Democratic Enterprise. Liberating of business through freedom, flexibility and commitment. Stockholm School of Economics in St. Petersburg]

Herzberg, F. 1959. The motivation to work. New York, Wiley.

CN Personnel. 2014. [Online] <http://www.cn.ca/en/delivering-responsibly/people〉. [Accessed 10 January 2014]

Pedersen\&Partners. 2014. [Online] <https://www.pedersenandpartners.com/>. [Accessed 10 January 2014]

Anchor. 2014. [Online] <http://ancorholding.spravka.ua/〉. [Accessed 8 January 2014]

Išoraite, M. 2013. Motivation tools though lenses of prospective employees, Entrepreneurship and Sustainability Issues 1(2):116-123. DOI: http://dx.doi.org/10.9770/jesi.2013.1.2(6)

Ivakina, L. 2009. Upravlenije personalom: Uchebnoje posobije [Personnel Management: Textbook] Moskva [Moscow].

Korsakienè, R.; Tvaronavičienè, M. 2014. Processes of economic development: case of Lithuanian real estate sector, Entrepreneurship and Sustainability Issues 1(3): 162-172. DOI: http://dx.doi.org/10.9770/jesi.2014.1.3(5) 
Caurkubule, Ž.; Rubanovskis, A. 2014. Pension system development and the sustainability of the principle of generation solidarity, Entrepreneurship and Sustainability Issues 1(3): 173-186. DOI: http://dx.doi.org/10.9770/jesi.2014.1.3(6)

Laužikas, M.; Mokšeckienè. 2013. The role of creativity in sustainable business, Entrepreneurship and Sustainability Issues 1(1): 10-22. DOI: http://dx.doi.org/10.9770/jesi.2013.1(2)

Mayo, E. 2007. The Human Problems of an Industrial Civilization. N.Y.

Maslow, A. H. 1954. Motivation and personality. Harper.

McGregor, D. 2006. The Human Side of Enterprise. The McGraw-Hill Companies.

Porter, L. W.; Lawler, E. E. 1968. Managerial Attitudes and Performance. Homewood, IL: Richard D. Irwin, Inc.

Raišienè, A.G.; Jonušauskas, S. 2013. Silent issues of ICT era: impact of techno-stress to the work and life balance of employees, Entrepreneurship and Sustainability Issues 1(2): 108-115. DOI: http://dx.doi.org/10.9770/jesi.2013.1.2(5)

Raudeliūnienè, J.; Tvaronavičienè, M.; Dzemyda, I. 2014.Towards economic security and sustainability: key success factors of sustainable entrepreneurship in conditions of global economy, Journal of Security and Sustainability Issues 3(4): 71-79. DOI: http://dx.doi.org/10.9770/jssi.2014.3.4(7)

Spitzer, D.R. 1995. Supermotivation. New York: AMACOM.

Tvaronavičienè, M. 2014. If industrial sector development is sustainable: Lithuania compared to the EU, Entrepreneurship and Sustainability Issues 1(3): 134-142. DOI: http://dx.doi.org/10.9770/jesi.2014.1.3(2)

Tvaronavičienè, M.; Šimelytė, A.; Lace, N. 2014. Sustainable development facets: exporting industrial sectors from inside, Journal of Security and Sustainability Issues 3(4): 37-44. DOI: http://dx.doi.org/10.9770/jssi.2014.3.4(4)

Vasiliūnaitè, R. 2014. Sustainable development: methodological approaches toward issues, Journal of Security and Sustainability Issues 3(3): 69-75. DOI: http://dx.doi.org/10.9770/jssi.2014.3.3(6)

Vroom, V. H. 1964. Work and Motivation. New York, Wiley.

Wahl, M.; Prause, G. 2013. Toward understanding resources, competencies, and capabilities: business model generation approach, Entrepreneurship and Sustainability Issues 1(2): 67-80. DOI: http://dx.doi.org/10.9770/jesi.2013.1.2(1)

Zhulina, E.; Ivanova, N. 2007. Jevropeiskije sistemi oplati truda [European wage system]. Upravlenie personalom (in Russian).

TNS Latvia. 2014. [Online] http://www.tns.lv/ [Accessed 5 February 2014]

Žanna CAURKUBULE - Assoc. Prof., Rector of Baltic Psychology and Management University College, Riga, Latvia. Research interests: social security, pension system, economic policy, sustainable development.

Aleksandrs RUBANOVSKIS - Assoc. Prof. at Baltic Psychology and Management University College, Riga, Latvia. Research interests: social security, pension system, economic policy.

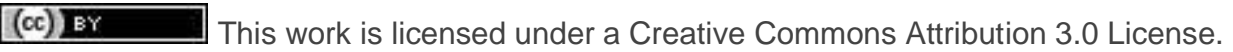

